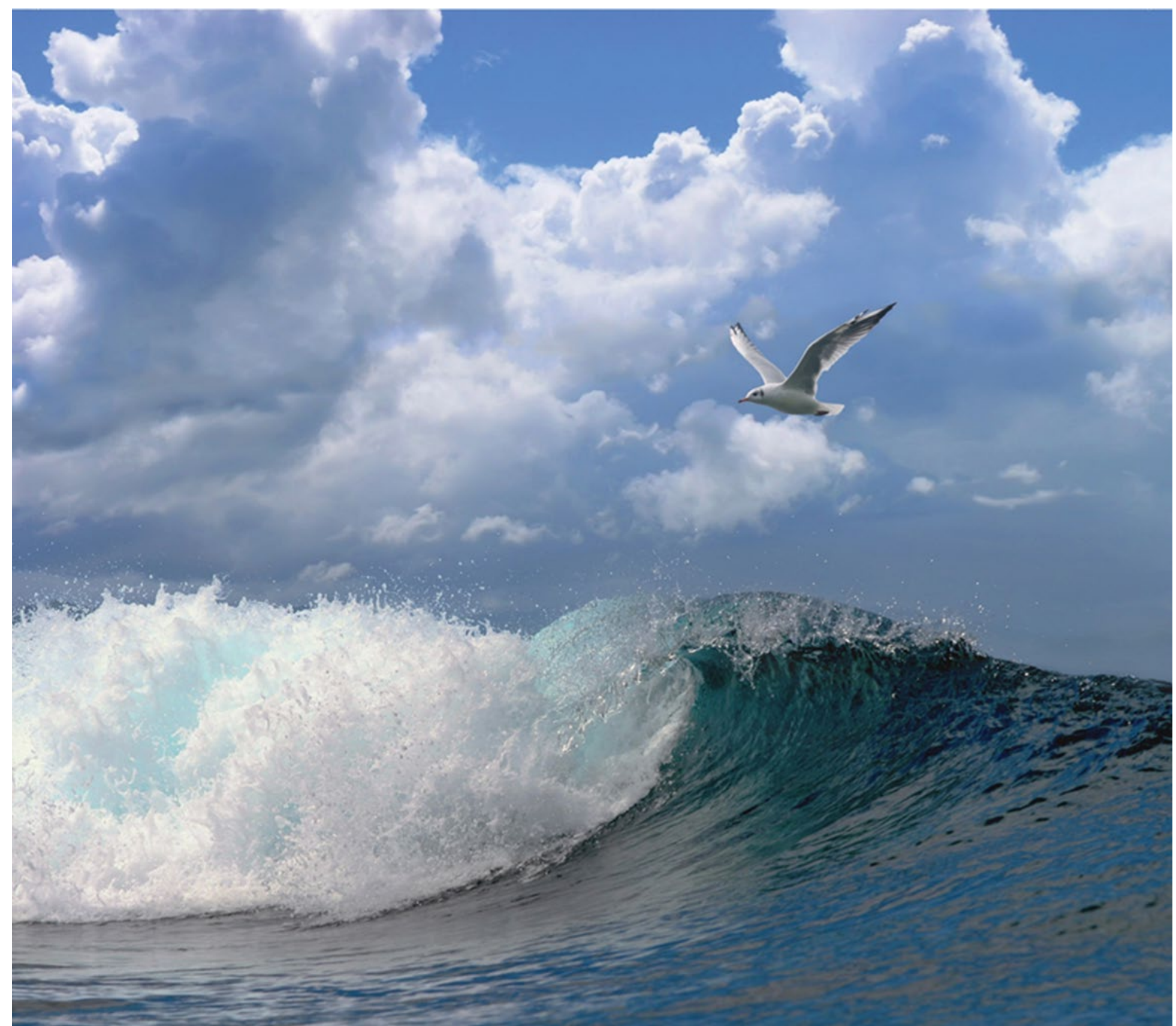

\title{
Aalonderzoek Hoogheemraadschap van Delfland: groei en verspreiding van rode aal (Anguilla anguilla) 2021
}

\section{Data rapportage}




\section{Aalonderzoek Hoogheemraadschap van Delfland: groei en verspreiding van rode aal (Anguilla anguilla) 2021}

Data rapportage

Auteur(s): A.B. Griffioen

Wageningen Marine Research

IJmuiden, oktober 2021

VERTROUWELIJK Nee

Wageningen Marine Research rapport C079/21 
Keywords: Rode aal, groeisnelheid, verspreiding, Delfland, PIT-tag

Opdrachtgever: Hoogheemraadschap van Delfland

T.a.v. W. van der Ende

Postbus 3061

2601 DB Delft

Dit rapport is gratis te downloaden van https://doi.org/10.18174/555595

Wageningen Marine Research verstrekt geen gedrukte exemplaren van rapporten.

Wageningen Marine Research is ISO 9001:2015 gecertificeerd.

\section{(C) Wageningen Marine Research}

Wageningen Marine Research, instituut binnen de rechtspersoon Stichting Wageningen Research, hierbij vertegenwoordigd door Drs.ir. M.T. van Manen, directeur bedrijfsvoering

KvK nr. 09098104, WMR BTW nr. NL 8113.83.696.B16. Code BIC/SWIFT address: RABONL2U IBAN code: NL 73 RABO 0373599285
Wageningen Marine Research aanvaardt geen aansprakelijkheid voor gevolgschade, noch voor schade welke voortvloeit uit toepassingen van de resultaten van werkzaamheden of andere gegevens verkregen van Wageningen Marine Research. Opdrachtgever vrijwaart Wageningen Marine Research van aanspraken van derden in verband met deze toepassing.

Alle rechten voorbehouden. Niets uit deze uitgave mag weergegeven en/of gepubliceerd worden, gefotokopieerd of op enige andere manier gebruikt worden zonder schriftelijke toestemming van de uitgever of auteur. 


\section{Inhoud}

$\begin{array}{lr}\text { Samenvatting } & 4\end{array}$

$1 \quad$ Inleiding $\quad 5$

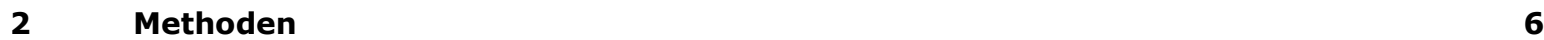

2.1 Merken vissen, studiegebied en fuiken 6

$\begin{array}{lll}2.2 & \text { Vaststellen groei } & 7\end{array}$

$\begin{array}{lll}2.3 & \text { Werkzaamheden en diefstal fuiken } 2021 & 7\end{array}$

$\begin{array}{llr}3 & \text { Resultaten } & 9\end{array}$

$\begin{array}{lll}3.1 & \text { Lengtemetingen en groeisnelheid } & 10\end{array}$

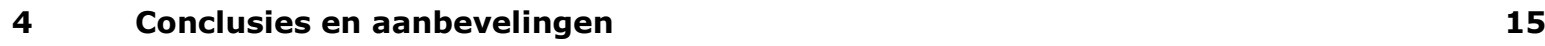

$\begin{array}{llr}5 & \text { Kwaliteitsborging } & 16\end{array}$

$\begin{array}{lr}\text { Literatuur } & 17\end{array}$

$\begin{array}{lr}\text { Verantwoording } & 18\end{array}$

$\begin{array}{llr}\text { Bijlage } 1 \quad \text { Lengte frequentie } & 19\end{array}$

$\begin{array}{llr}\text { Bijlage } 2 & \text { Fuik coördinaten } & 20\end{array}$ 


\section{Samenvatting}

Het Hoogheemraadschap van Delfland (HHD) heeft de afgelopen jaren bijgedragen aan het verbeteren van de overlevingskansen van Europese aal (Anguilla anguilla) in het beheergebied. Zo is er geïnvesteerd in het vispasseerbaar maken van kunstwerken. Ook is met de lokale beroepsvisserij overeengekomen te stoppen met aalvisserij in het gehele beheergebied van Delfland voor de periode 2017 t/m 2022 en te investeren in de ontwikkelingen van aal in het gebied door o.a. het doen van onderzoek.

De huidige studie betreft een merk-terugvangstexperiment van rode aal in vijf deelgebieden in boezemwater van HHD: Berkelse Zweth (BZ), Nieuwe Water (NW), Vlaardingse Vaart (VV), Boonervliet (BV) en het Verversingskanaal (VK) nabij gemaal Schoute. Het doel van het onderzoek is het vaststellen van variatie in groei en verspreiding van rode aal in het beheergebied. In 2017 (jaar 1) en 2018 (jaar 2) zijn in totaal 1008 rode alen van een $12 \mathrm{~mm}$ PITtag voorzien. Het onderzoek wordt in het veld uitgevoerd door visserijbedrijf $W$. den Boer met ondersteuning van vrijwilligers van de Hengelsportvereniging SVBD (Sport Visserij Belangen Delfland), GHV / Groene Hart en medewerkers van het HHD. Wageningen Marine Research begeleidt het onderzoek. Deze rapportage betreft een verslaglegging van het vijfde onderzoeksjaar 2021. De werkzaamheden van jaar 1, 2, 3 en 4 zijn in aparte rapportages gepubliceerd. In het vijfde jaar is geprobeerd om de alen die in jaar 1 en jaar 2 zijn gemerkt terug te vangen en opnieuw op te meten op lengte. Het onderzoek wordt nog één jaar voortgezet (2022).

Over alle jaren heen zijn 376 alen één of meer keer teruggevangen, incl. terugvangsten een aantal dagen na het merken. In 2021 zijn in totaal 66 verschillende alen teruggevangen van de 1008 gemerkte rode alen.

De groeisnelheid over alle onderzoeksjaren en alle gebieden van de alen die zijn teruggevangen, ligt op $41.9 \mathrm{~mm}$ per jaar en er is variatie tussen de gebieden. Op basis van de teruggekoppelde data is de gemiddelde groeisnelheid bij het Nieuwe Water het hoogst met $62.9 \mathrm{~mm}$ per jaar (Figuur 2). De laagste gemiddelde groei wordt gemeten in het Verversingskanaal (30.6 mm/jaar), gevolgd door het Boonervliet/Vlaardingse Vaart ( $41.0 \mathrm{~mm} / \mathrm{jaar}$ ) en Berkelse Zweth (50.4 mm/jaar).

In het jaar 2021 heeft het onderzoek minder hinder ondervonden van diefstal van fuiken. Echter, door de afname van terugvangsten worden terugvangsten relatief waardevoller. Aanbevolen wordt om hier vanuit het Hoogheemraadschap weer aandacht aan te geven voorafgaand aan het onderzoek in 2022. 


\section{$1 \quad$ Inleiding}

Het Hoogheemraadschap van Delfland (HHD) heeft de afgelopen jaren bijgedragen aan het verbeteren van de overlevingskansen van Europese aal in het beheergebied. $\mathrm{Er}$ is geïnvesteerd in het vispasseerbaar maken van kunstwerken en het verbeteren van de (ecologische) waterkwaliteit. Ook is met de lokale beroepsvisserij overeengekomen te stoppen met aalvisserij in het gehele beheergebied van Delfland voor de periode $2017 \mathrm{t} / \mathrm{m}$ 2022. Het is echter onbekend hoeveel glasaal het beheergebied op natuurlijke wijze binnenkomt, waar de aal heen gaat en hoe groot het aalbestand is. Delfland heeft dan ook besloten om in de periode 2017 t/m 2022 onderzoek te doen naar de intrek van glasaal (Griffioen et al. 2018 ) en de omvang van de aalpopulatie in het beheergebied. De beroepsvisserij wordt betrokken bij deze onderzoeken.

Een gezonde aalpopulatie is afhankelijk van verschillende factoren, zoals vrije migratie tussen opgroei,en paaigebieden. HHD wil investeren in deze vrije migratie en daarnaast ook de opgroeigebieden in hun beheer goed onderhouden. Goed gefaciliteerde intrek van glasaal, een goede leefomgeving voor rode aal en effectieve uittrekmogelijkheden van volwassen schieraal binnen HHD zal bijdragen aan de lokale, maar ook de algehele Europese aalpopulatie.

Deze studie betreft een merk-terugvangstexperiment van rode aal in vijf deelgebieden in boezemwateren van HHD. Het doel van het onderzoek is het vaststellen van variatie in groei en verspreiding van rode aal. Deze rapportage betreft een verslaglegging (datarapportage) van het vijfde onderzoeksjaar 2021 vergelijkbaar met voorgaande jaren (Griffioen and Schilder 2018, Griffioen 2019, 2020). Het onderzoek wordt voortgezet met het (terug)vangen van rode aal in jaar 6 (2022).

Dit onderzoek wordt begeleid door Wageningen Marine Research (WMR) en in het veld uitgevoerd door visserijbedrijf $W$. den Boer, met ondersteuning van vrijwilligers van de Hengelsportvereniging SVBD (Sport Visserij Belangen Delfland), Gravenhaagse Hengelsport Vereniging (GHV) / Groene Hart en medewerkers van HHD. De vrijwilligers van de SVBD, GHV / Groene Hart en medewerkers van Hoogheemraadschap van Delfland helpen niet alleen mee met het onderzoek, maar zorgen er ook voor dat er toezicht is bij alle veldwerkzaamheden. Door de COVID-19 pandemie is het onderzoek in 2021 uitgevoerd W. den Boer en Wil van der Ende (HHD).

Doel van het onderzoek:

Onderzoek naar de variatie in groeisnelheid en verspreiding van rode aal in het gebeid van HHD.

\section{Onderzoeksvraag:}

Wat is de groeisnelheid van (rode) aal in het beheergebied van HHD en wat is de variatie tussen deelgebieden? Wat is de omvang van de rode aalpopulatie in de onderzochte deelgebieden van HHD en is er meer inzicht te krijgen in de migratieroutes van de aal in het beheergebied?

Deze rapportage gaat voornamelijk in op een overzicht van de gegevens verzameld in 2021. 


\section{$2 \quad$ Methoden}

\subsection{Merken vissen, studiegebied en locaties fuiken}

In het beheergebied van HHD werd in 2017 en 2018 met behulp van fuiken rode aal gevangen in vijf gebieden in boezemwater (Figuur 1). De rode alen werden verdoofd in een oplossing van $0.5 \mathrm{ml} / \mathrm{L} 1$ phenoxy ethanol. Vervolgens werden de alen gemerkt met een $12 \mathrm{~mm}$ HDX-PITtag die met een naald werd ingebracht in de rugspier naast de rugvin. Elke tag heeft een unieke code. De code werd afgelezen met een manual PITtag reader. Het plaatsen van de fuiken en het zetten van de $12 \mathrm{~mm}$ PITtags is, na instructie van WMR in het veld voor het zetten van de PITtags en het vrijgeven van een ontheffing, zelfstandig uitgevoerd door visserijbedrijf W. den Boer. De rode alen werden (verdoofd) gemeten op millimeter nauwkeurig in een V-vormige aalmeetbak. In $2017(n=336)$ en $2018(n=672)$ zijn in totaal 1008 rode alen gemerkt met een PITtag. In vervolg jaren zijn geen rode alen meer gemerkt met een PITtag; het aantal van 1008 gemerkte rode alen werd voldoende geacht om voldoende groeigegevens te verzamelen. Op foto 1-4 zijn ter indicatie enkele handelingen van het (terug)vangen en meten weergegeven.

Binnen de studie zijn de deelgebieden Vlaardingse Vaart en Boonervliet samengevoegd, omdat de wateren met elkaar in verbinding staan én de fuiken relatief dicht bij elkaar staan (Figuur 1). Ten opzichte van de voorgaande rapportages zijn, op basis van nieuw verkregen gegevens in 2021, een aantal aanpassingen doorgevoerd in de database of zijn gegevens verwijderd door onduidelijkheden op veldformulieren.

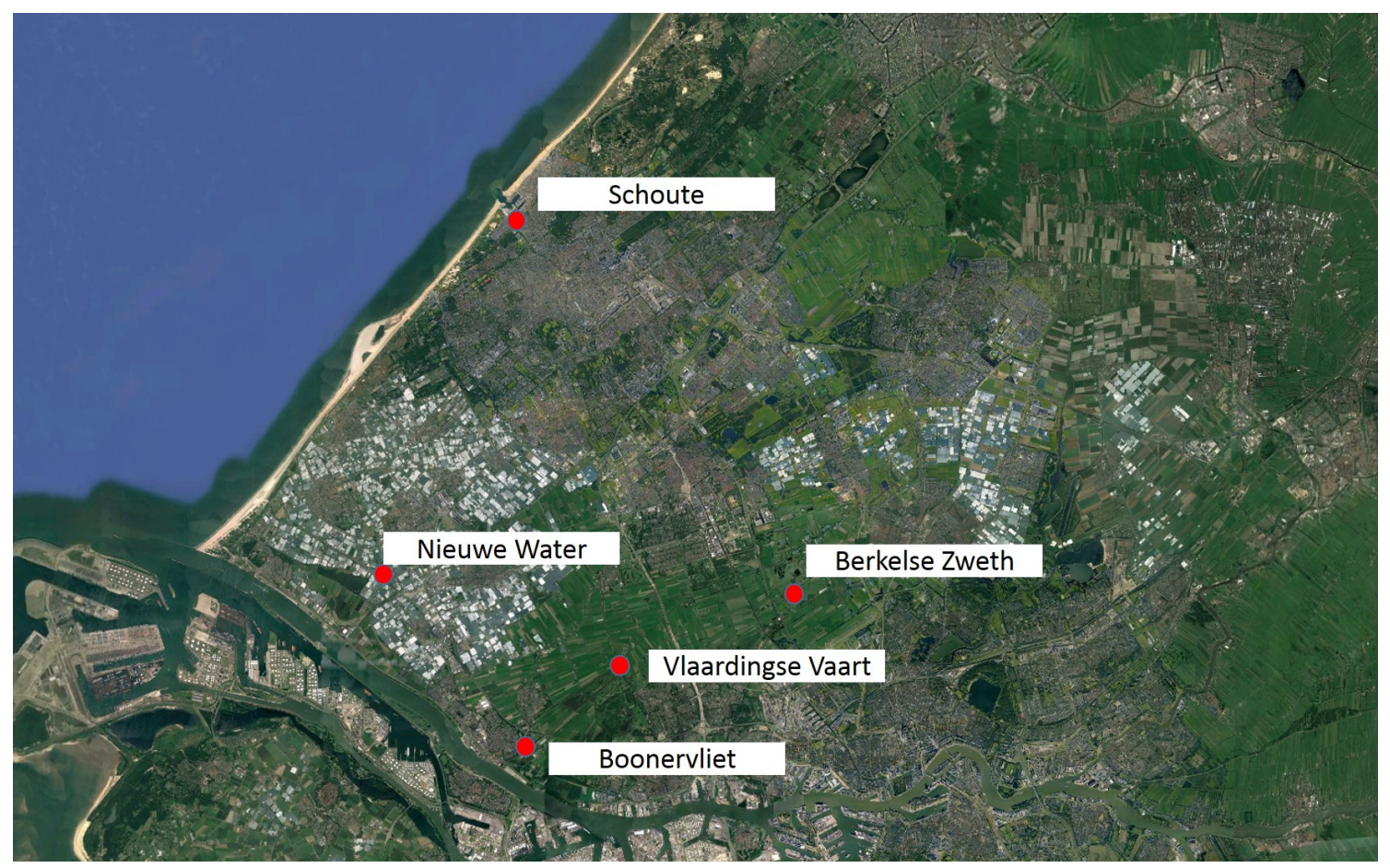

Op elke locatie zijn vier fuiken geplaatst. De monitoring in 2020 is gestart op 25 april 2021 met 20 fuiken en geëindigd op 6 juni 2021. De fuiken zijn in de vangstperiode twee keer verplaatst met de gedachte dat rode aal soms zeer lokaal actief is en de kans op (nieuwe) terugvangsten dan groter is. De fuiken zijn om de drie dagen gelicht: 28 april, 1, 5 (i.p.v. 4 mei i.v.m. storm), 7, 10, 13, 16, 19, 22, 25, 28, 31 mei, 3 en 6 juni. In totaal zijn er 14 lichtingen uitgevoerd. 
De fuiken zijn op 7 mei verplaatst $\left(1^{\text {ste }}\right)$ en, behalve op de Berkelse Zweth, op 25 mei $\left(2^{\text {de }}\right)$ nogmaals verplaatst. De fuiken van de Berkelse Zweth zijn op 31 mei verplaatst. Fuiklocaties (coördinaten) zijn gegeven in Bijlage 2 in de appendix.

\subsection{Vaststellen groei}

Van de terugvangsten werd per aal de lengte opgemeten (verdoofd). Doordat sommige alen meerdere malen teruggevangen werden, wordt er binnen deze rapportage een 'groei-jaar' vastgesteld. Dit is de groei in $\mathrm{mm}$ tussen twee terugvangsten in twee aparte jaren (circa 365 dagen groei). Om de groei van een aal te bepalen, is de lengte $(\mathrm{mm})$ op het moment van merken afgetrokken van de lengte op het moment van terugvangen. De groeisnelheid ( $\mathrm{mm} / \mathrm{jaar}$ ) is vervolgens bepaald door het lengteverschil te delen door het aantal dagen tussen merk en terugvangst x 365 dagen. Vervolgens is een gemiddelde groeisnelheid bepaald per onderzoeksjaar voor elke unieke aal om te voorkomen dat alen die meerdere malen zijn teruggevangen oververtegenwoordigd zijn. Als een aal in het merkjaar al is teruggevangen werd dit niet opgenomen in de berekeningen. Met andere woorden; de groeisnelheid werd pas bepaald als aantal dagen tussen merken en terugvangen groter was dan 60 dagen. In de rapportage is ook een relatieve groei bepaald, waarbij de gemeten lengte $(\mathrm{mm})$ bij terugvangst is gedeeld door de lengte op het moment van merken.

Een lengte-frequentie grafiek van de rode alen die zijn gevangen, maar geen merk hadden, is gegeven in Bijlage 1 in de appendix.

\subsection{Werkzaamheden en diefstal fuiken 2021}

Op 5 mei 2021 zijn de fuiken (vier stuks) in het Berkelse Zweth meegenomen na lichting in verband met werkzaamheden aan de kade en risico op schade aan de fuiken. Deze fuiken zijn op 7 mei weer teruggeplaatst. Op deze locatie zijn op 25 en 28 mei de fuiken niet gelicht, doordat de boot niet te water gelaten kon worden. De fuiken zijn op 31 mei gelicht.

Op 22 mei is fuik nr.6 op het Boonervliet / Vlaardingse Vaart kapot aangetroffen (mogelijk doorheen gevaren). Er zaten twee alen in, waarvan één gemerkte (\#941410). Deze aal heeft een kapotte staart. Onbekend is of dat bij eerdere vangsten ook al was bij deze vis.

In de periode 28 - 31 mei is deze fuik nr. 6 gestolen in de Boonervliet / Vlaardingse Vaart. Daarnaast zijn in dezelfde periode twee fuiken, nr. 1 en 4, op het Nieuwe Water door derden (illegaal) gelicht / losgemaakt. Fuik nr. 4 was ook verdwenen, maar is met dreggen teruggevonden. 


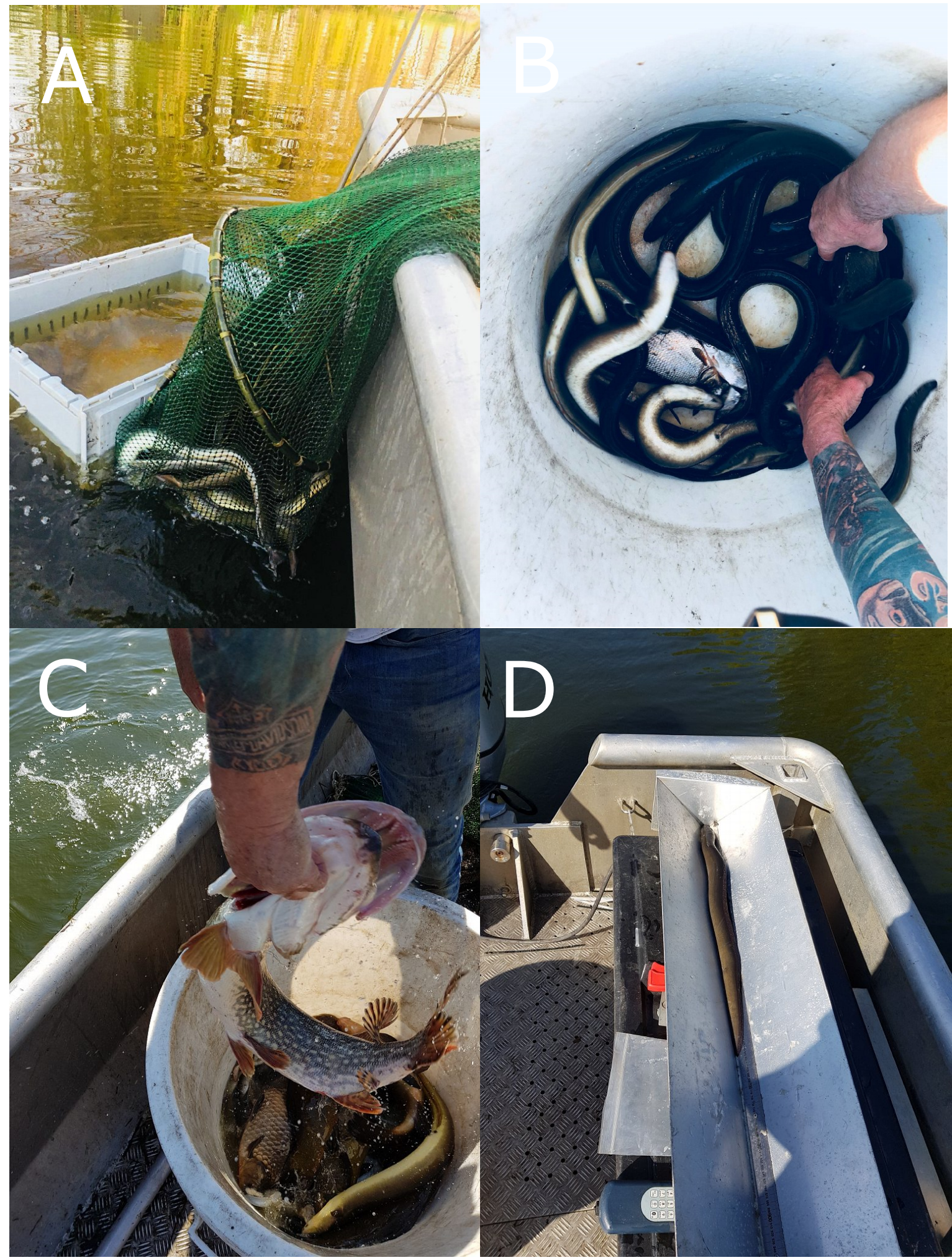

Foto 1-4. Foto's van het veldwerk. A: vangst wordt opgehaald uit een fuik. B: vangst wordt gesorteerd. C: bijvangst wordt direct teruggezet (hier een snoek en een giebel). D: rode aal wordt verdoofd gescand (PIT-tag) op terugvangst en opgemeten in een aalgoot. (Foto's uit 2019) 


\section{Resultaten}

In 2021 zijn in totaal 66 gemerkte rode alen teruggevangen waaronder enkele meerdere malen, waardoor het totale aantal terugvangsten van gemerkte alen 80 bedroeg. Van twee van deze alen (\#943058 en \#943205) zijn er geen lengtegegevens beschikbaar van het merkjaar (2017/2018) door verlies van het betreffende veldformulier, waardoor van 64 alen groeigegevens verzameld zijn. Gedurende het onderzoek nam het aantal unieke terugvangsten af (Figuur 1). In het onderzoek zijn tot nu toe (2017-2021) van de 1008 gemerkte rode alen 376 (37.3\%) unieke terugvangsten gedaan (Tabel 2).

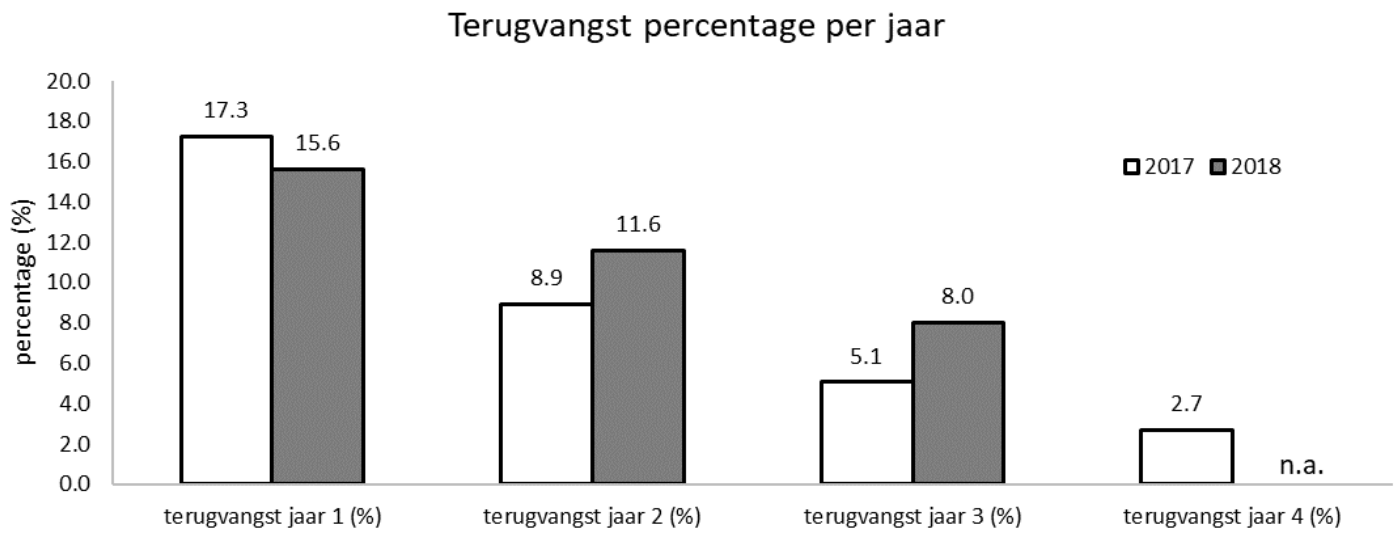

Over 2017-2021 zijn in totaal 376 alen een of meerdere malen teruggevangen. Het grootste deel van deze groep terugvangsten is eenmaal teruggevangen $(21.7 \% n=219$, Tabel 2$)$, gevolgd door tweemaal terugvangst $(8.2 \%, n=83)$, driemaal terugvangst $(3.2 \%, n=32)$ en viermaal $(2.1 \%, n=21)$. In totaal zijn vier alen meer dan 10 keer binnen het project gevangen ( 9,10 en 12 keer terugvangst).

Tabel 2. Totaal aantal terugvangsten over alle onderzoeksjaren (2017-2020) per gebied. BO_VV = Boonervliet en Vlaardingse Vaart, BZ = Berkelse Zweth, $N W=$ Nieuwe Water, VK = Verversingskanaal.

aantal keer teruggevangen (2017-2021)

\begin{tabular}{|c|c|c|c|c|c|c|c|c|c|c|c|c|c|c|c|}
\hline & & Gemerkt & & & 3 & 4 & 5 & 6 & 7 & 8 & 9 & 10 & 11 & 12 & totaal \\
\hline \multirow[t]{2}{*}{ BO_VV } & $\mathrm{n}$ & 596 & 121 & 38 & 12 & 11 & 2 & 0 & 1 & & & & & & 185 \\
\hline & $\%$ & & 20.3 & 6.4 & 2.0 & 1.8 & 0.3 & 0.0 & 0.2 & & & & & & 31.0 \\
\hline \multirow[t]{2}{*}{$B Z$} & $\mathrm{n}$ & 214 & 48 & 21 & 8 & 5 & 2 & 1 & & & & & & & 85 \\
\hline & $\%$ & & 22.4 & 9.8 & 3.7 & 2.3 & 0.9 & 0.5 & & & & & & & 39.7 \\
\hline \multirow[t]{2}{*}{ NW } & $\mathrm{n}$ & 95 & 25 & 8 & 3 & 1 & & & & & & & & & 37 \\
\hline & $\%$ & & 26.3 & 8.4 & 3.2 & 1.1 & & & & & & & & & 38.9 \\
\hline \multirow[t]{2}{*}{ VK } & $\mathrm{n}$ & 103 & 25 & 16 & 9 & 4 & 3 & 2 & 5 & 1 & 2 & 1 & & 1 & 69 \\
\hline & $\%$ & & 24.3 & 15.5 & 8.7 & 3.9 & 2.9 & 1.9 & 4.9 & 1.0 & 1.9 & 1.0 & & 1.0 & 67.0 \\
\hline \multirow[t]{2}{*}{ Totaal } & $\mathrm{n}$ & 1008 & 219 & 83 & 32 & 21 & 7 & 3 & 6 & 1 & 2 & 1 & & 1 & 376 \\
\hline & $\%$ & & 21.7 & 8.2 & 3.2 & 2.1 & 0.7 & 0.3 & 0.6 & 0.1 & 0.2 & 0.1 & & 0.1 & 37.3 \\
\hline
\end{tabular}

Naast de gemerkte rode aalvangsten zijn in 2021 ook 1304 ongemerkte rode alen gevangen en 73 ongemerkte schieralen. Van vijf gemerkte alen was bij terugvangst aangemerkt dat dit een schieraal betrof (\#941373, \#941403, \#941444, \#941513 en \#942043). In 2020 was dit ook het geval met \#941311 en \#941444. Deze laatste aal (\#941444) is in 2021 echter nogmaals teruggevangen en is dus niet uitgetrokken (en wederom aangemerkt als schieraal). In 2021 zijn van twee alen (\#941339 en \#941410) aangemerkt dat deze een stuk staart missen. Dit is eerder in het onderzoek niet opgemerkt. 
Mogelijk zullen deze daarom een vertekende groei laten zien. In een volgende analyse wordt beoordeeld of deze alen uit de dataset moeten worden verwijderd indien de afwijkende patronen laten zien.

In de fuiken zijn, net als voorgaande jaren, niet alleen alen gevangen, maar ook bijvangsten zoals grote zeelt, brasem, giebel, snoek, Chinese wolhandkrabben en Amerikaanse rivierkreeften. Aan deze bijvangsten wordt in dit onderzoek geen aandacht besteed.

\subsection{Lengtemetingen en groeisnelheid}

De groeisnelheid over alle onderzoeksjaren en alle gebieden van de teruggevangen alen ligt op 41.9 $\mathrm{mm}$ per jaar. Er is variatie tussen de gebieden. Op basis van de teruggekoppelde gegevens is de gemiddelde groeisnelheid in het Nieuwe Water het hoogst met $62.9 \mathrm{~mm}$ per jaar (Figuur 2). De laagste gemiddelde groei wordt gemeten in het Verversingskanaal (30.6 mm/jaar), gevolgd door de Boonervliet/Vlaardingse Vaart $(41.0 \mathrm{~mm} / \mathrm{jaar})$ en Berkelse Zweth $(50.4 \mathrm{~mm} / \mathrm{jaar})$. Er zijn binnen dit onderzoek diverse alen gevonden die over 1, 2, 3 en 4 jaar geen groei realiseerden. Dit heeft invloed op de gemiddelde groei per gebied. Er is geen verschil in groeisnelheid tussen jaren (Figuur 3). Met andere woorden; de jaarlijkse groei tussen 2018, 2019, 2020 en 2021 is vergelijkbaar.

\section{groeisnelheid rode aal $\mathrm{mm} / \mathrm{jaar}$}

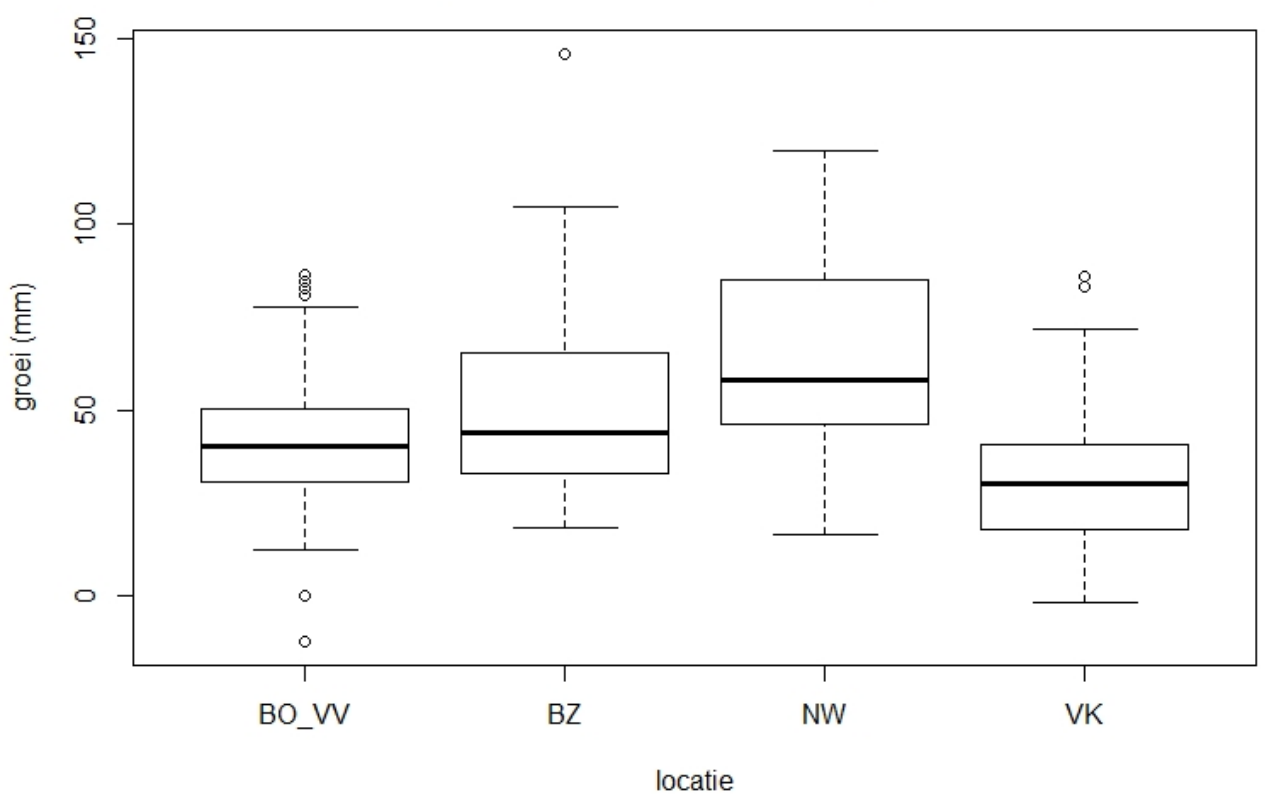

Figuur 2. Groeisnelheden per gebied (mm/jaar). De groeisnelheid per teruggevangen aal wordt bepaald door het verschil in lengte $(\mathrm{mm})$ en tijdverschil. $\mathrm{BO}=$ Boonervliet, $\mathrm{VV}=$ Vlaardingse Vaart, $\mathrm{BZ}=$ Berkelse Zweth, NW = Nieuwe Water, VK = Verversingskanaal. 
groeisnelheid rode aal $\mathrm{mm} / \mathrm{jaar}$

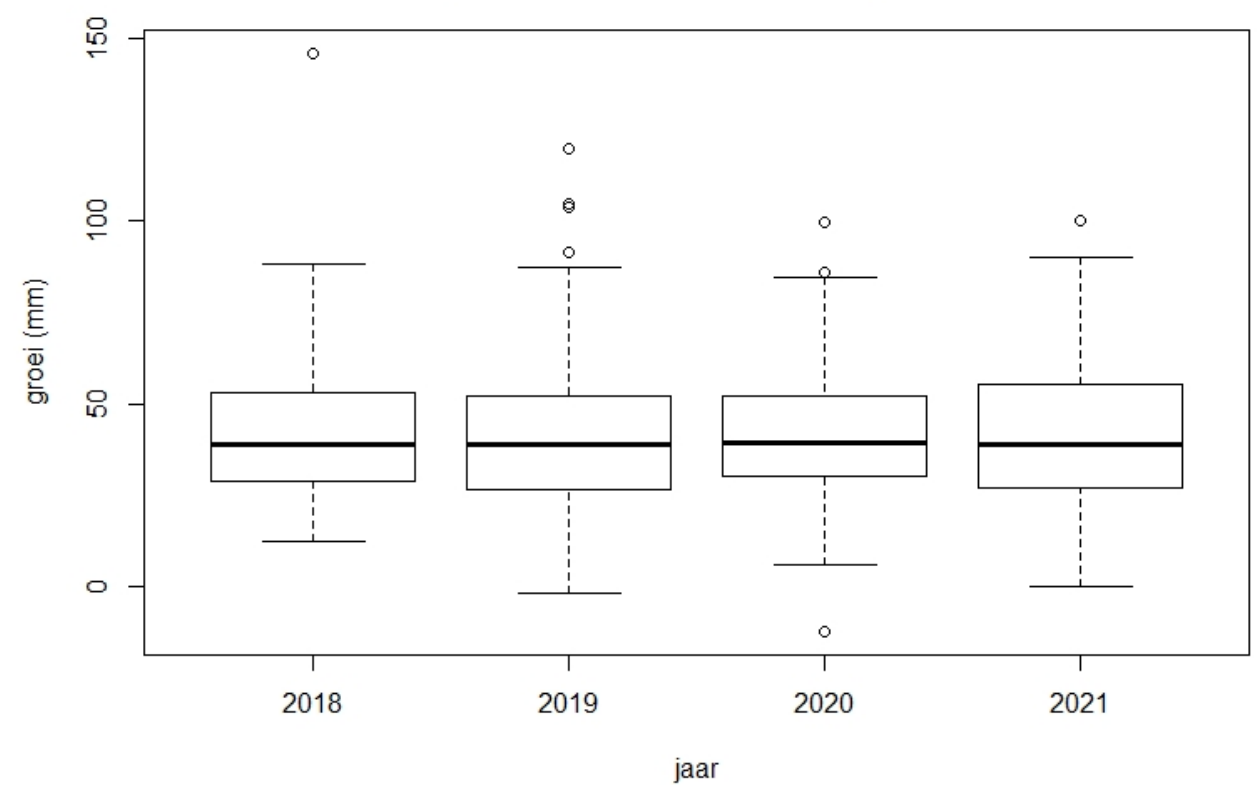

Figuur 3. Groeisnelheden per jaar ( $\mathrm{mm} /$ jaar). De groeisnelheid per teruggevangen aal wordt bepaald door het verschil in lengte $(\mathrm{mm})$ en tijdverschil.

Naast de spreiding van groeigegevens per jaar, is ook gekeken naar de relatieve groei. Deze groei is bepaald door de relatieve groei te berekenen t.o.v. de startlengte. Bij meerdere terugvangsten binnen één jaar is eerst een gemiddelde lengte bepaald met een gemiddelde tijd tussen merken en terugvangst. Hierdoor ontstaat één waarde per seizoen. $\mathrm{Er}$ is een grote variatie zichtbaar tussen de individuele alen (Figuur 4). De sterkste stijging in groei waren twee individuen met ruim $29 \%$ groei per jaar (terugvangst na 741 en 1093 dagen). Afgezien van twee individuen die een krimp lieten zien (mogelijk door meetfouten), was de kleinste groei van twee individuen $0.1 \%$ groei per jaar (terugvangsten na 339 en 357 dagen).
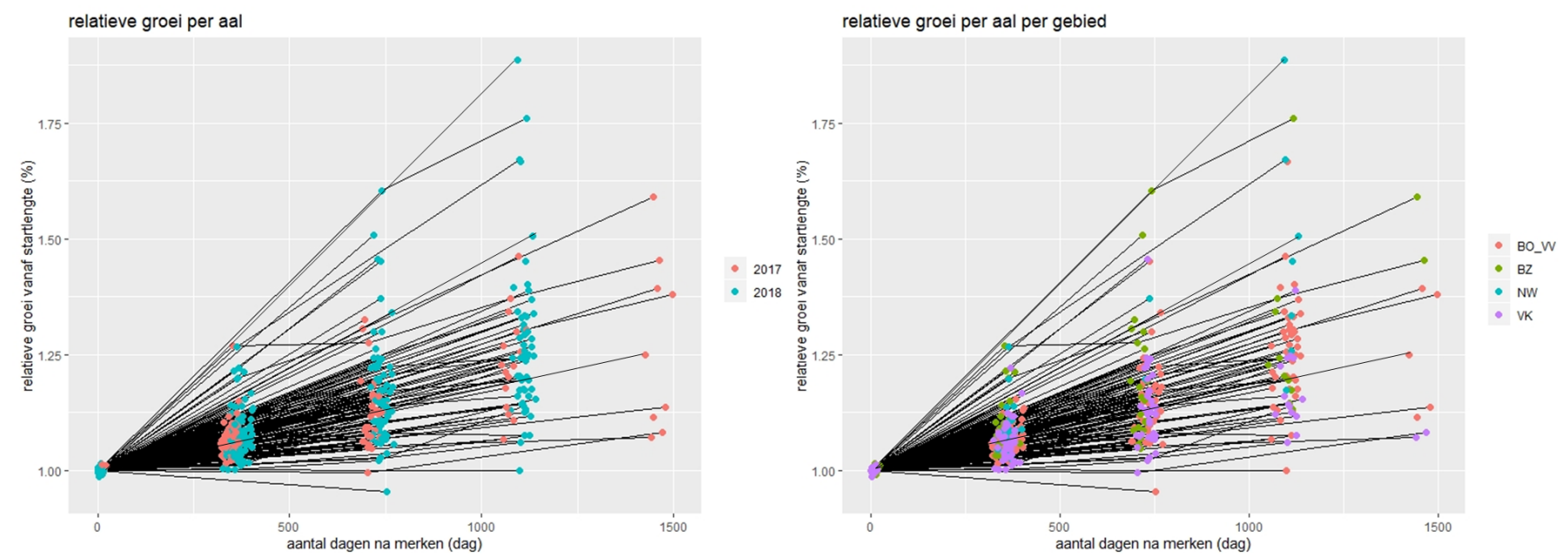

Figuur 4. Relatieve groei ten opzichte van het moment van merken. Er is onderscheid gemaakt in de groep die in 2017 is gemerkt en de groep die in 2018 is gemerkt. Links de verschillende merkjaren en rechts dezelfde grafiek met onderscheid in gebieden. Negatieve waarden zijn mogelijk het gevolg van foutieve notaties. BO_VV = Boonervliet en Vlaardingse Vaart, BZ = Berkelse Zweth, NW = Nieuwe Water, VK = Verversingskanaal.

Binnen deze datarapportage worden enkele voorbeelden gegeven van lengteverschil in de tijd (Figuren 5 en 6). In sommige gevallen is de groei over enkele jaren minder dan $14 \mathrm{~mm}$ per jaar (Figuur 5). Ook zijn er alen sinds 2017 of 2018 meerdere jaren teruggevangen (Figuur 6) en is er een enkel geval waarbij de aal is teruggevangen in een ander gebied dan dat het gemerkt is (\#943100, Figuur 7 en Figuur 8). Over het algemeen lijken de alen 'honkvast'. 

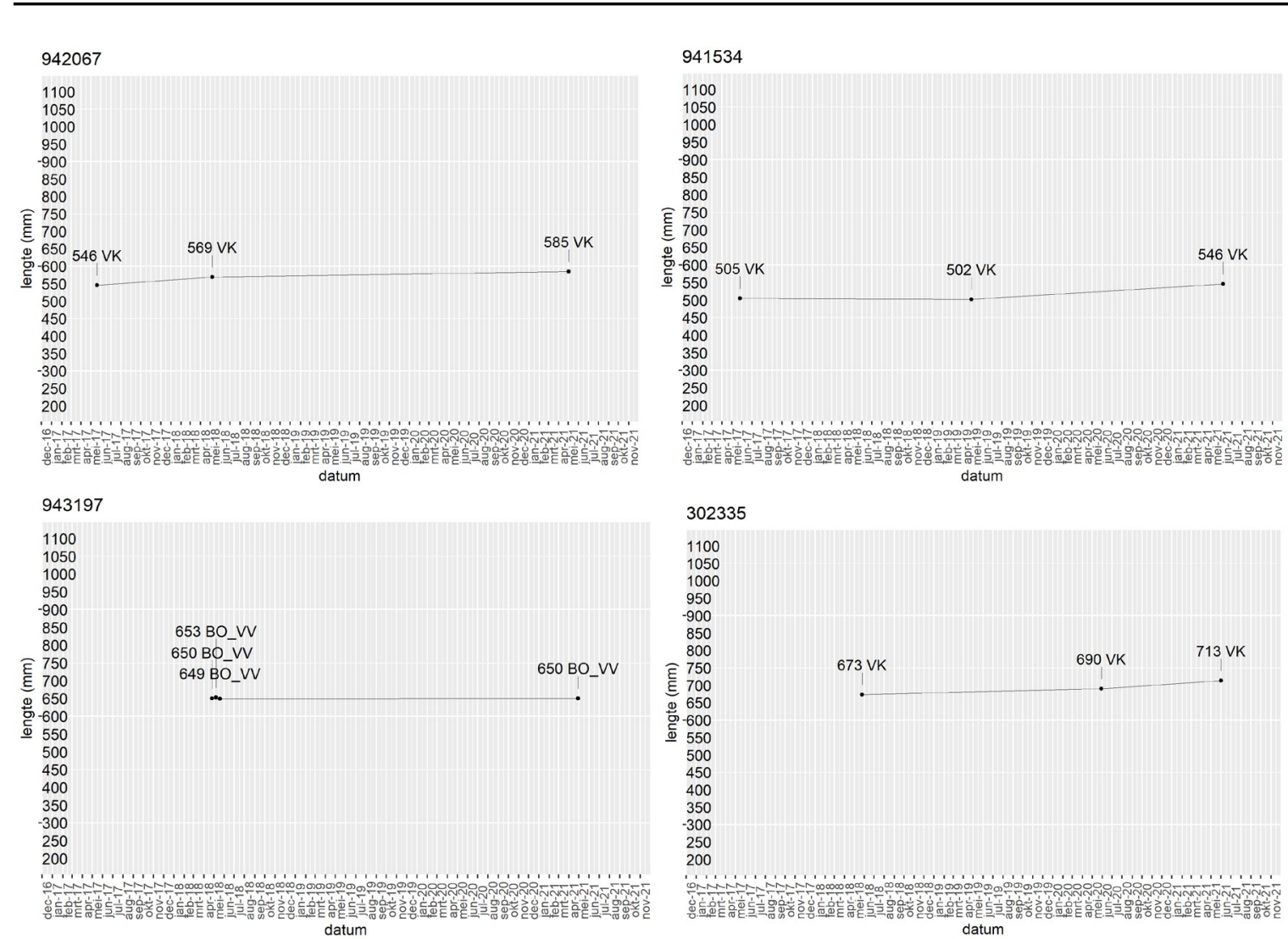

Figuur 5. Individuele groei van alen die nauwelijks groei laten zien over 4 jaar ( $<14 \mathrm{~mm}$ per jaar). BO_VV = Boonervlieten Vlaardingse Vaart, BZ = Berkelse Zweth, NW = Nieuwe Water, VK = Verversingskanaal. 

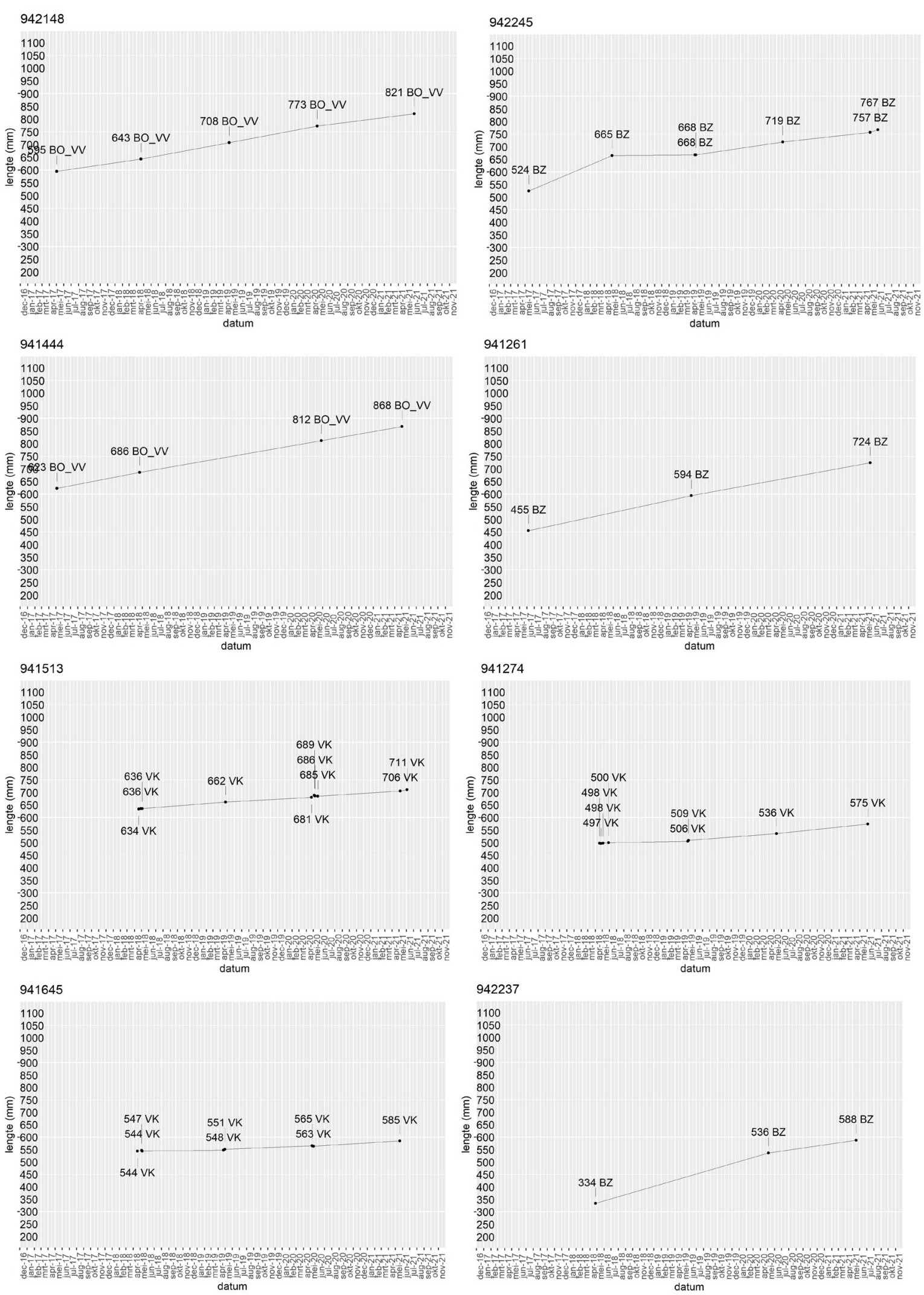

Figuur 6. Individuele groei van alen die sinds 2017 of 2018 meerdere jaren zijn gevangen. BO_VV = Boonervliet en Vlaardingse Vaart, BZ = Berkelse Zweth, NW = Nieuwe Water, VK = Verversingskanaal. 


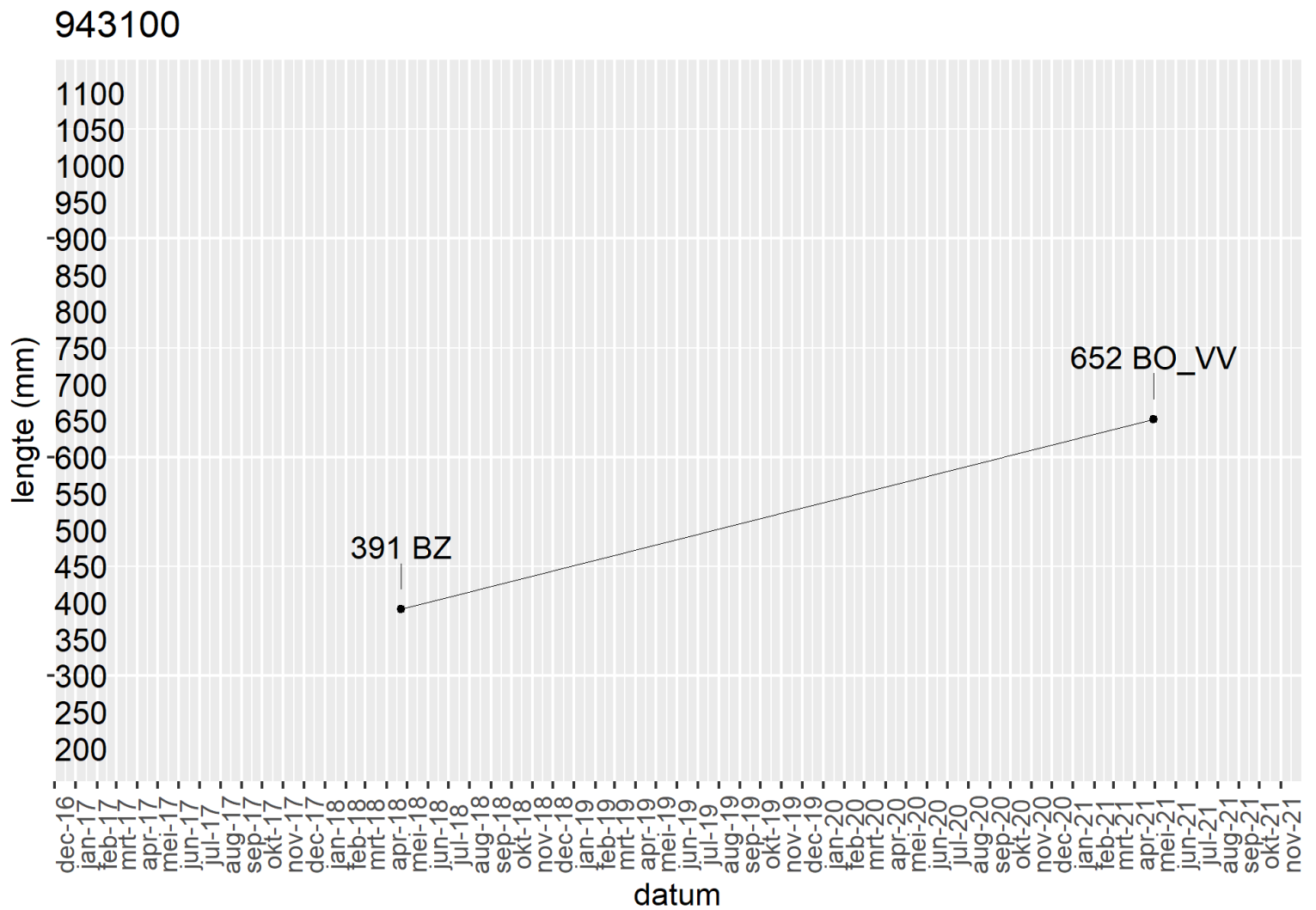

Figuur 7. Een aal die op 22 april 2018 is gemerkt in de Berkelse Zweth en op 5 mei 2021 is teruggevangen in de Boonervliet(/Vlaardingse Vaart) fuik 1. BO_VV = Boonervliet en Vlaardingse Vaart, $\mathrm{BZ}=$ Berkelse Zweth.

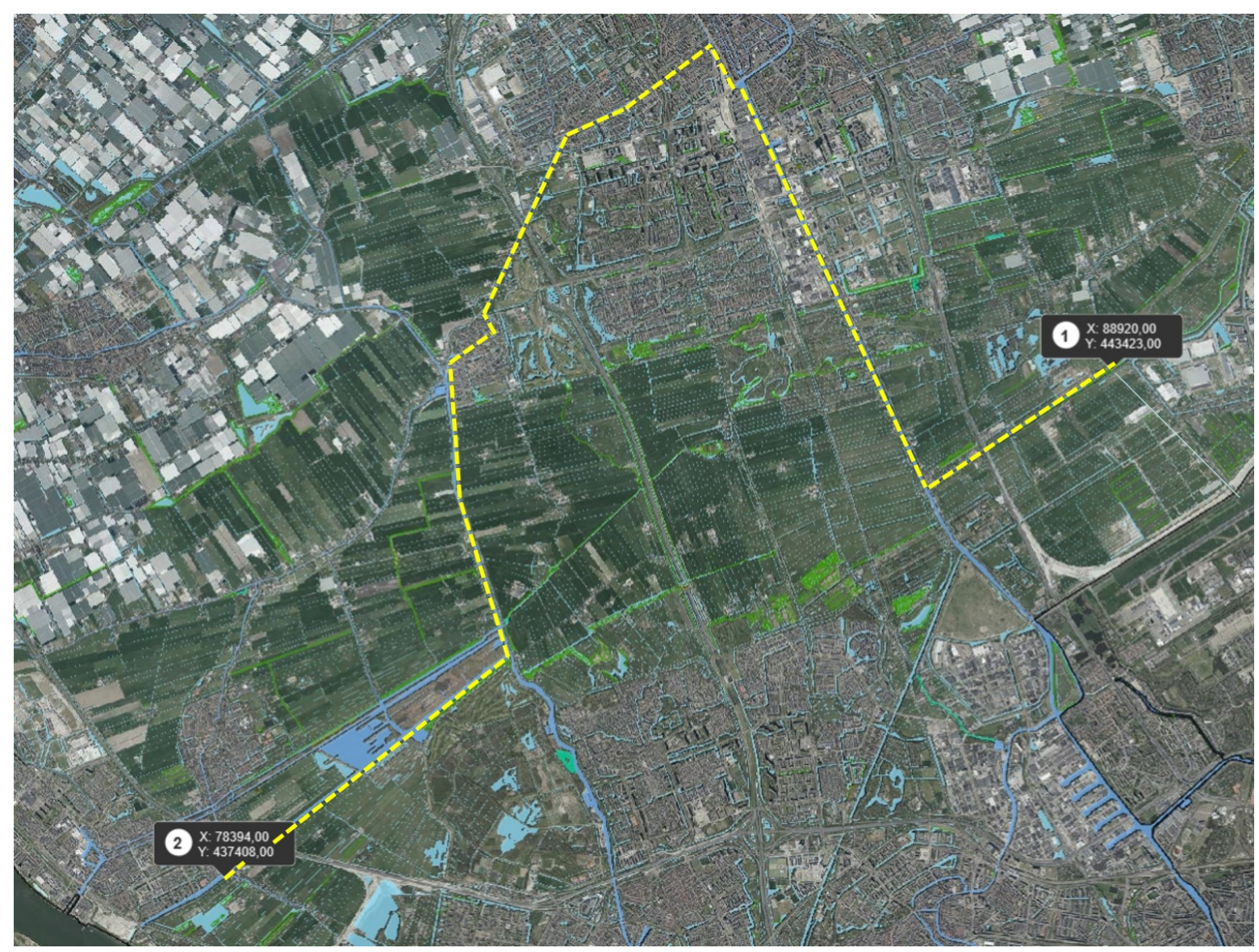

Figuur 8. De kortste route die aal \#943100 via het boezemwater tussen 2018 en 2021 mogelijk heeft afgelegd, om van de Berkelse Zweth (1) te komen in de fuik in de Boonervliet (2). 


\section{$4 \quad$ Conclusies en aanbevelingen}

Het doel van de rapportage is een weergave te geven van de gemiddelde groei van rode aal in de diverse gebieden. In 2021 zijn in totaal 66 verschillende alen teruggevangen van de 1008 gemerkte rode alen $(6.5 \%)$. De groei varieerde sterk tussen individuen met $0.1-29 \%$ groeien over een jaar.

De groeisnelheid over alle onderzoeksjaren en alle gebieden van de alen die zijn teruggevangen, ligt op $41.9 \mathrm{~mm}$ per jaar en er is variatie tussen de gebieden. De variatie tussen gebieden bestond tussen 30.6 en $62.9 \mathrm{~mm}$ per jaar. Er zijn binnen dit onderzoek diverse alen gevonden die over 1, 2, 3 en 4 jaar geen groei realiseerden. Een van de gemerkte alen (\#943100) is boezemkanaal gevangen (2021, Boonervliet) dan dat deze aal gemerkt is (2018, Berkelse Zweth).

\section{Aanbevelingen}

Aanbevolen wordt om net als voorgaande jaren de alen in verdoofde toestand te meten. Op deze manier blijft de groei vergelijkbaar tussen de jaren.

In het jaar 2021 heeft het onderzoek minder hinder ondervonden van diefstal van fuiken. Echter, door de afname van terugvangsten, worden terugvangsten relatief waardevoller. Aanbevolen wordt om hier vanuit het Hoogheemraadschap weer aandacht aan te geven voorafgaand aan het onderzoek in 2022 door communicatie over het onderzoek en contact met handhavers. De variatie in groei tussen de alen is groot en daarom is het wenselijk om de trefkans van terugvangsten te optimaliseren door het plaatsen van voldoende fuiken in het onderzoeksgebied. 


\section{$5 \quad$ Kwaliteitsborging}

Wageningen Marine Research beschikt over een ISO 9001:2015 gecertificeerd kwaliteitsmanagementsysteem. Dit certificaat is geldig tot 15 december 2021. De organisatie is gecertificeerd sinds 27 februari 2001. De certificering is uitgevoerd door DNV GL. 


\section{Literatuur}

Griffioen, A. B. 2019. Aalonderzoek Hoogheemraadschap van Delfland: groei en verspreiding van rode aal (Anguilla anguilla) 2019. Wageningen Marine Research, IJmuiden.

Griffioen, A. B. 2020. Aalonderzoek Hoogheemraadschap van Delfland: groei en verspreiding van rode aal (Anguilla anguilla) 2020 : een datarapportage. Wageningen Marine Research, IJmuiden.

Griffioen, A. B., and K. Schilder. 2018. Aalonderzoeken Hoogheemraadschap van Delfland: groei en verspreiding van rode aal (Anguilla anguilla) 2018. Wageningen Marine Research, IJmuiden.

Griffioen, A. B., M. E. Schiphouwer, H. V. Winter, and S. Ploegaert. 2018 Aalonderzoeken Hoogheemraadschap van Delfland: efficiëntie van glasaalintrek bij gemaal Schoute Wageningen Marine Research report C007.18. 


\section{Verantwoording}

Rapport C079/21

Projectnummer: 4316100192

Dit rapport is met grote zorgvuldigheid tot stand gekomen. De wetenschappelijke kwaliteit is intern getoetst door een collega-onderzoeker en het verantwoordelijk lid van het managementteam van Wageningen Marine Research

Akkoord:

Ir. Olvin van Keeken

Onderzoeker

Handtekening:

Datum:

20 oktober 2021

Akkoord:

Drs. Jakob Asjes

MT lid

Handtekening:

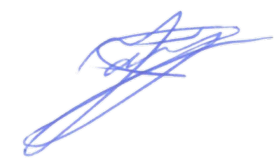

Datum:

20 oktober 2021 


\section{Bijlage 1 Lengte frequentie}
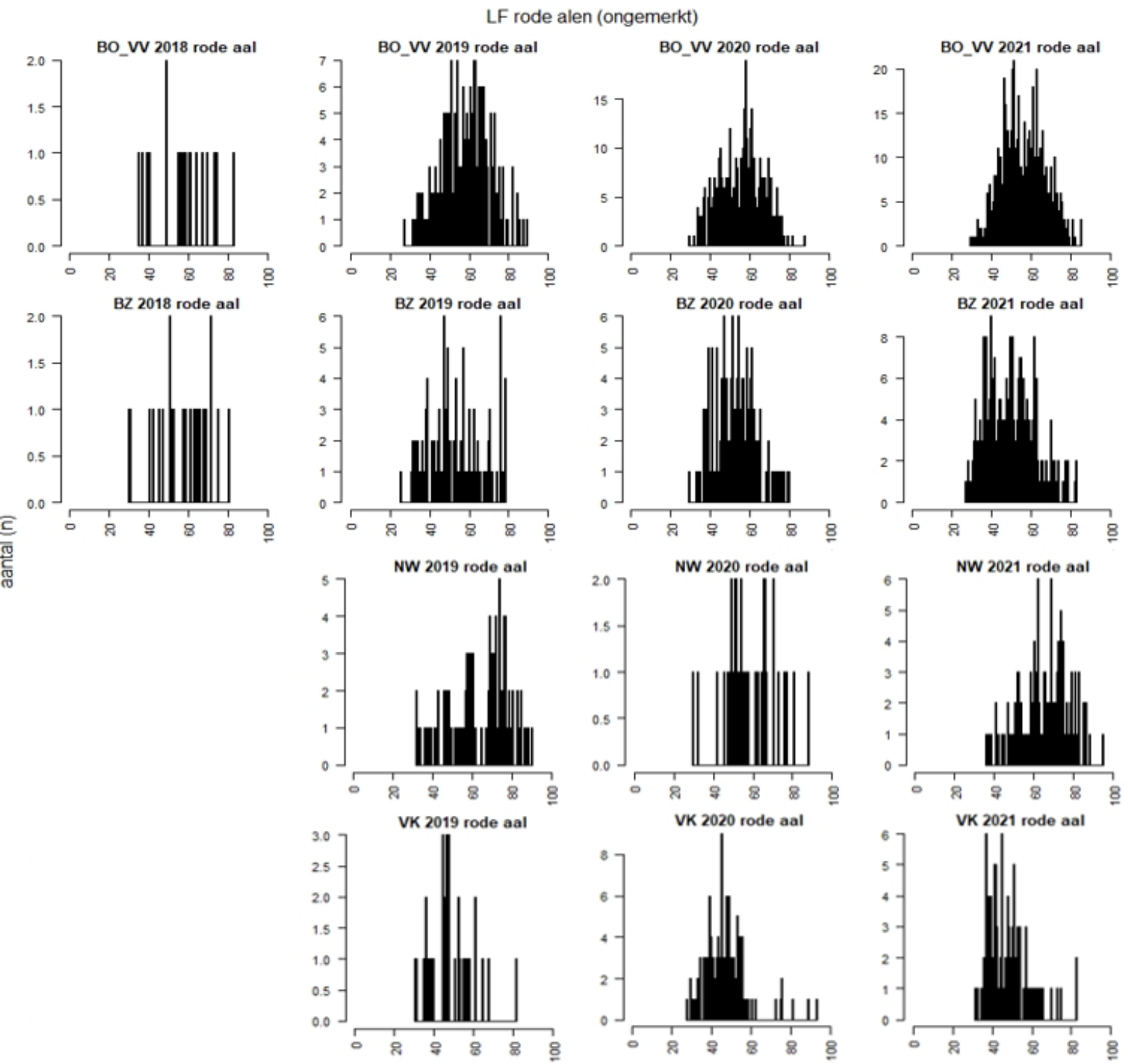

lengte $(\mathrm{cm})$

Figuur A. Lengte frequentie van rode alen die zijn gevangen maar geen merk hebben. NB. in 2017 en 2018 zijn vrijwel alle rode alen van een merk voorzien. Deze zijn niet opgenomen in dit overzicht. BO $=$ Boonervliet, $\mathrm{VV}=$ Vlaardingse Vaart, BZ $=$ Berkelse Zweth, NW = Nieuwe Water, VK = Verversingskanaal. 


\section{Bijlage 2 Fuik coördinaten}

\begin{tabular}{|c|c|c|c|}
\hline \multirow{3}{*}{$\begin{array}{l}\text { datum } \\
25 / a p r / 21\end{array}$} & Locatie & X-coordinaat & Y coordinaat \\
\hline & Berkelsche Zweth & 089054 & 443513 \\
\hline & Berkelsche Zweth & 088930 & 443447 \\
\hline & Berkelsche Zweth & 088694 & 443279 \\
\hline & Berkelsche Zweth & 088472 & 443152 \\
\hline & Boonervliet/Vlaardingese Vaart & 078394 & 437408 \\
\hline & Boonervliet/Vlaardingese Vaart & 078129 & 437213 \\
\hline & Boonervliet/Vlaardingese Vaart & 078606 & 437565 \\
\hline & Boonervliet/Vlaardingese Vaart & 079400 & 438220 \\
\hline & Boonervliet/Vlaardingese Vaart & 080476 & 439170 \\
\hline & Boonervliet/Vlaardingese Vaart & 008279 & 439703 \\
\hline & Boonervliet/Vlaardingese Vaart & 081809 & 439949 \\
\hline & Boonervliet/Vlaardingese Vaart & 082074 & 439689 \\
\hline & Nieuwe water & 073450 & 443034 \\
\hline & Nieuwe water & 073458 & 443294 \\
\hline & Nieuwe water & 072996 & 443638 \\
\hline & Nieuwe water & 072980 & 443829 \\
\hline & Verversingskanaal & 078311 & 456223 \\
\hline & Verversingskanaal & 078457 & 456100 \\
\hline & Verversingskanaal & 078506 & 456003 \\
\hline & Verversingskanaal & 078601 & 455900 \\
\hline $7 / \mathrm{mei} / 21$ & Berkelsche Zweth & 088255 & 443010 \\
\hline & Berkelsche Zweth & 088161 & 442956 \\
\hline & Berkelsche Zweth & 088058 & 442878 \\
\hline & Berkelsche Zweth & 087947 & 442820 \\
\hline & Boonervliet/Vlaardingese Vaart & 078320 & 437351 \\
\hline & Boonervliet/Vlaardingese Vaart & 078000 & 437138 \\
\hline & Boonervliet/Vlaardingese Vaart & 078719 & 437663 \\
\hline & Boonervliet/Vlaardingese Vaart & 079546 & 438298 \\
\hline & Boonervliet/Vlaardingese Vaart & 080394 & 439242 \\
\hline & Boonervliet/Vlaardingese Vaart & 081398 & 439789 \\
\hline & Boonervliet/Vlaardingese Vaart & 081920 & 439702 \\
\hline & Boonervliet/Vlaardingese Vaart & 082169 & 439551 \\
\hline & Nieuwe water & 073518 & 443078 \\
\hline & Nieuwe water & 073494 & 443251 \\
\hline & Nieuwe water & 072936 & 443696 \\
\hline & Nieuwe water & 072969 & 443950 \\
\hline & Verversingskanaal & 078377 & 456192 \\
\hline & Verversingskanaal & 078452 & 456070 \\
\hline & Verversingskanaal & 078542 & 455994 \\
\hline & Verversingskanaal & 078619 & 455833 \\
\hline $25 / \mathrm{mei} / 21$ & Berkelsche Zweth & onbekend, later verzet & onbekend, later verzet \\
\hline & Berkelsche Zweth & onbekend, later verzet & onbekend, later verzet \\
\hline & Berkelsche Zweth & onbekend, later verzet & onbekend, later verzet \\
\hline & Berkelsche Zweth & onbekend, later verzet & onbekend, later verzet \\
\hline & Boonervliet/Vlaardingese Vaart & 078251 & 437301 \\
\hline & Boonervliet/Vlaardingese Vaart & 077938 & 437115 \\
\hline & Boonervliet/Vlaardingese Vaart & 078933 & 437821 \\
\hline & Boonervliet/Vlaardingese Vaart & 079681 & 438427 \\
\hline & Boonervliet/Vlaardingese Vaart & 080323 & 439410 \\
\hline & Boonervliet/Vlaardingese Vaart & 081499 & 439869 \\
\hline & Boonervliet/Vlaardingese Vaart & 082125 & 439656 \\
\hline & Boonervliet/Vlaardingese Vaart & 082224 & 439490 \\
\hline & Nieuwe water & 073545 & 443088 \\
\hline & Nieuwe water & 073404 & 443335 \\
\hline & Nieuwe water & 072929 & 443717 \\
\hline & Nieuwe water & 072961 & 444023 \\
\hline & Verversingskanaal & 078373 & 456156 \\
\hline & Verversingskanaal & 078492 & 456061 \\
\hline & Verversingskanaal & 078573 & 455907 \\
\hline & Verversingskanaal & 078689 & 455702 \\
\hline
\end{tabular}


Wageningen Marine Research

T: $+31(0) 317487000$

E: marine-research@wur.nl

www.wur.nl/marine-research

Bezoekers adres:

- Ankerpark 271781 AG Den Helder

- Korringaweg 7, 4401 NT Yerseke

- Haringkade 1, 1976 CP IJmuiden
Wageningen Marine Research levert met kennis, onafhankelijk wetenschappelijk onderzoek en advies een wezenlijke bijdrage aan een duurzamer, zorgvuldiger beheer, gebruik en bescherming van de natuurlijke rijkdommen in zee-, kust- en zoetwatergebieden. 
